\title{
Bioremediations Technologies on Wastewater Treatment: Opportunities, Challenges and Economic Perspective
}

\author{
Dewi Rosanti ${ }^{1}$, Yudha Gusti Wibowo ${ }^{2 *}$, Muhammad Safri ${ }^{3}$, Anis Tatik Maryani ${ }^{4}$, \\ Bimastyaji Surya Ramadan ${ }^{5}$ \\ *email: yudhagustiwibowo26@gmail.com \\ ${ }^{1}$ Faculty of Science and Mathematics, Universitas PGRI Palembang, Indonesia \\ ${ }^{2,3,4}$ Postgraduate program of Environmental Science, Universitas Jambi, Indonesia \\ ${ }^{5}$ Environmental Engineering Department, Universitas Diponegoro, Indonesia
}

\begin{abstract}
Bioremediation is one of high value and low-cost technologies to solve environmental degradation. In this paper, we made a systematic review of bioremediation utilization for wastewater treatment. This paper aims to describe the current bioremediation technologies, potential microorganisms involved, recent bioremediation treatment research to solve environmental damage and economic comparation of bioremediations processes. The regulatory of heavy metals limitation in drinking water is also reported in this paper. Thus, this paper described comprehensive information on bioremediation in the world and this future research direction.
\end{abstract}

Keywords: bioremediation, wastewater treatment, biological treatment.

\section{INTRODUCTION}

Industrial activities have been impacting the environment, such as air pollution (Yang et al., 2019), contaminated soil (Peruchi et al., 2015), and wastewater (Naswir et al., 2019). These impacts will have some negative implications for human health, plant, animal, and environmental degradation. Wastewater impact indicated by low $\mathrm{pH}$ and high heavy metals content. Some industries were generated wastewater, such as coal and small-scale gold mining, palm oil mill effluent. These industrial wastes need to be treated.

A recent study informs several methods to solve wastewater treatment, such as physical, chemical, and biological treatment. Most wastewater treatments were developed, such as the sorption process, including adsorption, absorption, ion-exchange, and hydrogen bonding. However, these processes have some limitations, such as need high technology to produce high sorption of sorbent and complicated sorption models, high technology to the analysis process.

Although the sorption technologies were developed, this model does not fit to apply in rural areas. As we know, most of the industrial activity has been operating in rural areas in Indonesia. This condition pushes the researcher to develop the new treatment that useful in a rural area. Kalimantan is one of the sample about the centralization coal mining industry in this place. Coal mining has been producing from $1740 \mathrm{M}$ Sumatera also has a mining industry, especially in Jambi. In this location, the mining industry has centralized on Tebo, Mandiangin, Sarolangun, and Bungo. They are the rural area. Environmental pollution caused by industrial activities recently attracted public attention 
because of its high heavy metal concentration. In Batang Asai Jambi, Hg's concentration is high, driven by illegal gold mining and affected by the environmental sector. This illegal activity was impacted sound and dust pollution, a decrease in water quality and quantity on the Batang Asai river, diminishing the forest conservation. The Batang Asai River was silting and widening, decreasing of Semah Fish (Tor sp.), the occurrence of the hole due to illegal gold mining activities, an abrasion on the outskirts of the Batang Asai River, and the land around the hole due to illicit gold mining activities (Susanti et al., 2018).

Compared with chemical and physical remediation, bioremediation has one of potential remediation for wastewater treatment. Bioremediation has the advantages of no or minimum nuisance, no secondary pollution, lowcost treatment, simple preparation, and in-situ remediation (Xia et al., 2019). Bioremediation methods are the most reliable wastewater treatment and having high environmental, economic, ecological, and social benefits (Rayu et al., 2012). Bioremediation is remediation based on biologically-derived materials such as raw materials from organic waste (i.e., agriculture waste), forestry, biochar, and living organisms such as plants, bacteria, fungi, and algae, respectively. Biosorption involves the sorption and enrichment of wastewater parameters by biologically-derived living organisms and raw materials to reduce the waste parameters (heavy metals) on wastewater (Bwapwa et al., 2017; Oya et al., 2017; Verma \& Kuila, 2019). These two approaches could reduce the heavy metals (i.e., $\mathrm{Cr}, \mathrm{Pb}, \mathrm{Fe}, \mathrm{Mn}$ ) to migrate and its bioavailability.

In recent decades, much of the reviews have thus far been published to explain and describe the use of biologicallyderived materials and living organisms for wastewater remediation. We provided a systematic and comprehensive review of bioremediation using biologicallyderived and living organisms. This review focus on various dimensions of heavy metals bioremediation trials. We described summarizing current knowledge of massive metals source, environmental quality, toxicological and human impact, and analytic methods. We also discuss the potential of bioremediation. Finally, we consider a new research direction and prospects in bioremediation on wastewater treatments.

\section{Bioremediation}

Bioremediation is the biological process of decontamination of pollutants in the environment (Goltapeh et al., 2013). The setting may be either aqueous, terrestrial, or both of them. Bioremediation also means cleaning up the contaminants in the environment by exploiting microorganisms' diverse metabolic abilities to reduce the pollutants (Megharaj et al., 2011). Bioremediation has been classified into in-situ bioremediation and ex-situ bioremediation (Hatzinger et al., 2002). In-situ bioremediation is applied to pollutants removal from the environment (soils and groundwater) (Menendez-Vega et al., 2007). This method is promoted due to the low-cost way, saves transportation costs, and uses harmless microorganisms to reduce the chemical contaminants (Science \& Sharma, 2012). In-situ bioremediation also classified into two types: Intrinsic bioremediation: This in-situ bioremediation is carried out without direct microbial amendment and using metabolic and naturally microfauna by improving ventilation and nutrition condition, and the second in-situ bioremediation is engineered in-situ bioremediation, this in-situ bioremediation performed trough use the particular microorganism to a contamination environment (soil or water), in this method nitrogen and phosphorous used to grow up the 
development of microorganisms (Hunkeler et al., 2002). The second of bioremediation is ex-situ bioremediation. This bioremediation process takes place somewhere out from contaminated soil or water and needs to transport contaminated materials using pumping (water) and other transportation for soil. Ex-situ bioremediation could be classified into two phases: solid-phase system and slurry phases system. The solid phase system is used to produce organic waste and domestic problems bioremediation. This bioremediation is also used for industrial waste, sewage sludge, and municipal concrete waste removal (Loehr et al., 2001). Three processes of this ex-situ bioremediation are soil bio-pilling, land-farming, and composting. The second of ex-situ bioremediation is slurry phase systems; this system promotes solid-liquid suspensions in bioreactors. This method is a relatively rapid process than other treatment processes (Venkata Mohan et al., 2009).

Bioremediation techniques are bioaugmentation, biofilters, bioreactors, bio-stimulation, bio-venting, composting, landfarming or land treatment, or prepared bed bioreactors, bio-piling. Biostimulation can be applied for in-situ and ex-situ bioremediation using indigenous microbial in soil and groundwater. Bioventing is the process of drawing oxygen through the contaminated environment to stimulate activity and growth of microbial. This treatment is using indigenous bacteria supplied by air and nutrients from contaminated soil. This treatment works for hydrocarbons contaminated and can be used if the contamination deep under the surface. This treatment will be decisive when the depth of contamination around 30-60 cm. Composting is an aerobic and thermophilic process and mixes of contaminated soil with a bulking agent. This treatment may be applied with status piles, aerated piles, or a continuously fed reactor. Composting is a technique that involves combining the contaminated soil with non-hazardous organic amendments (organic waste or manure). This treatment typically ranges of temperature around 55-65 ${ }^{0} \mathrm{C}$. Landfarming can be applied in ex-situ and in-situ bioremediation. This method is promoted for spilled oil and wood-preserving. Biopoling is the bioremediation of contaminated sites using bio-pilers. This treatment can be used to hydrocarbon contaminated soil (Adams et al., 2015; Jones \& Wilson, 1993; Karigar \& Rao, 2011).

\section{Heavy Metals in the Environment}

Heavy metals are toxic contaminants in the environment, including soil and water (Wibowo et al., 2019; Wibowo \& Naswir, 2019). Heavy metals were contaminated soil and water, heavy metals contaminated in the water at coal mining area is called acid mine drainage. Several places were defiled of heavy metals in Indonesia, such as Grasberg Mine in Papua, Bukit Asam coal mining company, this condition not happened only in Indonesia. Unfortunately, heavy metal contaminated on the water does not occur in Indonesia, Susquehanna River, Pennsylvania, USA. Rodalquilar, Spain reported their environment was contaminated with heavy metals in stream sediments. Mount Morgan in Queensland, Australia, also spoiled groundwater resources. Yuxi Basin, Hunan, China is also contaminated on heavy metals with a high concentration in surface water, river sediments, groundwater, tailings, and soil from waste rock and tailings (Werner et al., 2019). Heavy metals are also found in the house environment (i.e., lead from paint) (Wilson, 2006). Heavy metals are also found in various anthropogenic activities, including smelting, mining, fertilizer, and pesticide application in 
agricultural activity, electroplating, electronic manufacturing. All of these activities have impacted heavy metals in the aquatic environment (Chen et al., 2017).

A recent study reported that heavy metals contaminated in the world's southernmost mussel farm, Beagle Channel, Argentina. They are reported that five heavy metals in sediment and gill and digestive gland of mussels were examined to consider the potential risk to human health in Argentina. In their paper, the authors informed that this area has high metal bioaccumulation such as $\mathrm{Zn}, \mathrm{Fe}, \mathrm{Cu}, \mathrm{Cd}$, and $\mathrm{Pb}$. In this study, the authors collected sediment samples and measured in the laboratory. The heavy metals were measured by a Perkin Elmer AA-2380 atomic absorption spectrophotometer using air- acetylene flame and deuterium background correction $\quad\left(\mathrm{D}_{2} \mathrm{BGC}\right)$ Metals bioaccumulation also found in mussel tissues from Argentina and reported that metals range between $91 \%$ and $103 \%$ and has low metals contaminated such as $\mathrm{Cu}$, $\mathrm{Zn}, \mathrm{Fe}$, and $\mathrm{Pb}$ (Channel et al., 2010)

One of the metals with high toxicology is Chromium $(\mathrm{Cr})$; this metal ion has valence states ranging between 0 to IV. The high valence states are more stable species in the environment (e.g., $\mathrm{Cr}(\mathrm{III})$ and $\mathrm{Cr}(\mathrm{IV}))$. In the soil environment, $\mathrm{Cr}$ (III) and $\mathrm{Cr}(\mathrm{IV})$ have entirely different properties. $\mathrm{Cr}$ (III) exists mainly in $\mathrm{Cr}^{3+}, \mathrm{Cr}(\mathrm{OH})_{2}{ }^{+}, \mathrm{Cr}(\mathrm{OH})^{2+}$,
$\mathrm{Cr}(\mathrm{OH})_{3}, \quad \mathrm{Cr}(\mathrm{OH})_{5}^{2-}$ and $\quad \mathrm{Cr}(\mathrm{OH})_{4}^{-}$ (Mendoza et al., 2007) and $\mathrm{Cr}(\mathrm{IV})$ exist mainly in $\mathrm{CrO}_{4}{ }^{2-}, \mathrm{Cr}_{2} \mathrm{O}_{7}{ }^{2-}$ and $\mathrm{HCrO}_{4}^{-}$. $\mathrm{Cr}(\mathrm{IV})$ is more toxic than $\mathrm{Cr}$ (III). These elements have a high solubility in the environment, and these compounds more easily migrate in pore water (Mendoza et al., 2007). Heavy metals in the environment are also produced from sulfide oxidation. This process generated wastewater called acid mine drainage. Acid mine drainage has high heavy metals contamination such as $\mathrm{Fe}, \mathrm{Mn}$, $\mathrm{Mg}, \mathrm{Al}, \mathrm{Ag}$, etc. (Wibowo \& Naswir, 2019; Wibowo \& Syarifuddin, 2018).

Heavy metals on acid mine drainage are also produced by the biological sulfur cycle (Fig. 1). The reaction in Fig. 1, including the dissimilatory reduction of sulfate. The sulfate reduction is coupled with energy conservation and growth, dissimilatory reduction, and assimilatory reduction. The reduced amount of sulfide is assimilated in proteins, amino-acids biomass, and cofactors by microorganisms, plants, and fungi. Mineralization of organic compounds with the release of hydrogen sulfide. Oxidation of sulfide by $\mathrm{NO}_{3}^{-}, \mathrm{Fe}^{3+}, \mathrm{O}_{2}$, and $\mathrm{Mn}^{4+}$ as electron acceptors by phototropic and lithotropic bacteria, producing sulfate and sulfur subsequently, and the last is coupled oxidation and sulfur reduction including thiosulfate, sulfite, and sulfur to sulfate and sulfide (Villegas-plazas et al., 2019). 


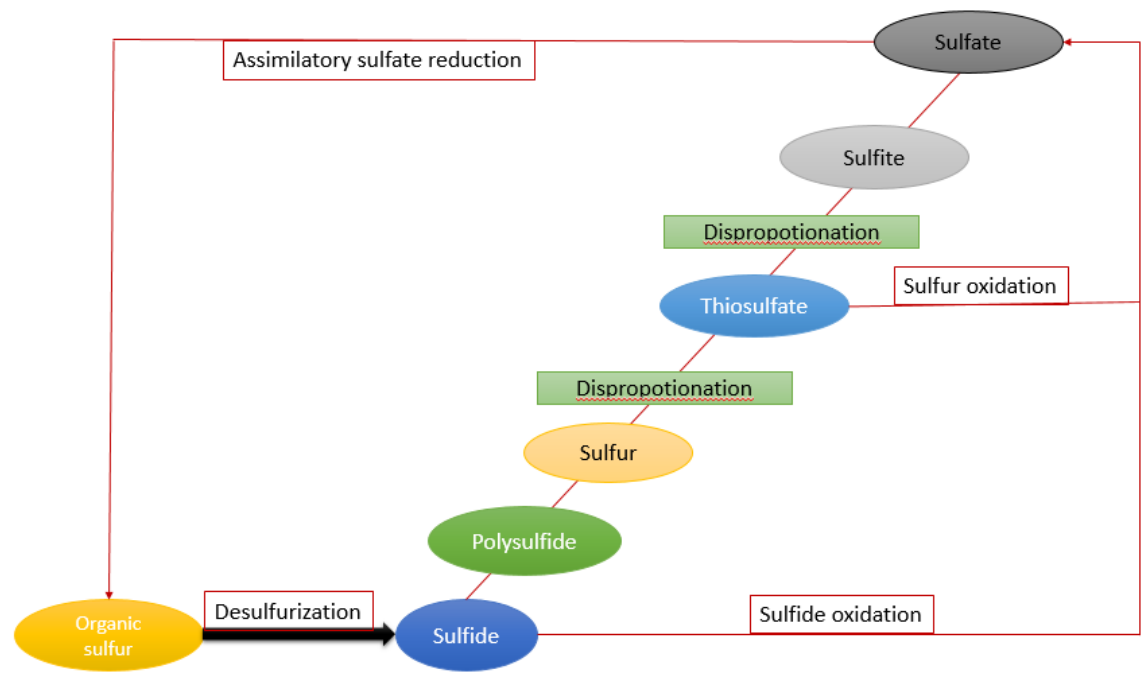

Figure 1. Transformation of biological sulfur

Heavy metals are also found in dust road in Beijing, China. Chong Men reported that spatial variation and identification of heavy metals source in dust road in Beijing. They used the Nemerow Integrated Risk Index (NIRI) to identify and analyze the risk index. In this paper, the authors informed that heavy metals (i.e., $\mathrm{Cd}, \mathrm{As}, \mathrm{Cu}, \mathrm{Cr}, \mathrm{Ni}, \mathrm{Mn}$, and $\mathrm{Pb}$ ) have a strong tendency to accumulate and easy to transferred through the food chain. Dust road was collected at $115.7^{0}$ $117.4^{0} \mathrm{E}, 39.4^{0}-41.6^{0} \mathrm{~N}$, located in the China Plain's northwest area. Based on this research, $22 \%$ is an extreme risk during spring; fuel combustion is the largest contributor to heavy metals (34.21\%) (Men et al., 2019).

A recent study reported that 168 rivers and 71 lakes polluted from 1972 until 2017. In this study, researchers analyzed 12 heavy metals $(\mathrm{Cd}, \mathrm{Pb}, \mathrm{Cr}$, $\mathrm{Hg}, \mathrm{Zn}, \mathrm{Cu}, \mathrm{Ni}, \mathrm{Al}, \mathrm{Fe}, \mathrm{Mn}, \mathrm{As}$, and $\mathrm{Co}$ ) in the bodies of rivers and lakes. From 1972 until 2017, heavy metal changed from single metal pollution into mixed metal pollution. Over time, the sources of heavy metals in water bodies in the world are from mining and manufacturing industries (Zhou et al., 2020); during 2004 , the concentration of heavy metals in Nigeria river water amounted to 30 $\mu \mathrm{g} . \mathrm{L}^{-1}$ for $\mathrm{Pb}, 50 \mu \mathrm{g} . \mathrm{L}^{-1}$ for $\mathrm{Cd}, 2080$ $\mu \mathrm{g} . \mathrm{L}^{-1}$ for $\mathrm{Cr}$ and $780 \mu \mathrm{g} . \mathrm{L}^{-1}$ for $\mathrm{Ni}$. Heavy metals are also founded in the environment, such as contaminated soil caused by petroleum, oil, and gas activity (Zhang et al., 2019).

\section{Heavy Metals Impact}

Heavy metals in the environment will give some negatives impact. A recent study informed that heavy metals from mining activity impacted mining tailing leachate on soil quality. This paper reported the effect of heavy metals from mining activity in batch and column leaching test, the result of this study showed that $\mathrm{Cr}, \mathrm{Cu}, \mathrm{Ni}, \mathrm{Zn}, \mathrm{As}, \mathrm{Cd}$ and $\mathrm{Pb}$ impacted soil quality. These metals have high ecological risks. This study also informed that contaminated heavy metals from mining activity would have implications for surface water and soil, irrigated by local surface water (Wang et al., 2019). Heavy metals are well recognized for their negative impacts caused by their toxicity and human health risk, even at low levels. A recent study reported groundwater quality in Punjab, India. Its 18 sites were analyzed for physicochemical characteristics, water quality, heavy metals content $(\mathrm{Cd}, \mathrm{Co}$, $\mathrm{Cr}, \mathrm{Pb}, \mathrm{Zn}$ ), and impacts on adults and 
children during the winter and summer seasons. They collected 18 samples, 9 and 7 samples in summer and 18 , and 8 samples in winter. The mean of noncancer risk quotients for cobalt is 5.097.63 or $>1$. Cumulative risks posed by all heavy metals are 6.00-10.11, also $>1$. These results indicated a higher risk of non-cancerous health problems for Ropar Wetland, Punjab, India. Based on this research, groundwater in Punjab, India, has a high contaminant of heavy metals. This condition may pose a severe health risk to human health via drinking water ad irrigation of agricultural fields due to heavy metals from bioconcentration in food crops cultivated in those areas (Sharma et al., 2019).

Heavy metals pollution is related to human health risks including in soils around an electronics manufacturing facility. This study reported from Xiangyang city, Hubei Province, Central China, this total area is $19.774 \mathrm{~km}^{2}$ and population size of more than 5.5 million people. This condition leads to a high concentration of heavy metals such as $\mathrm{Cr}$, $\mathrm{Cu}, \mathrm{Zn}, \mathrm{As}, \mathrm{Cd}, \mathrm{Pb}$, and $\mathrm{Ni}$. These heavy metals are contributed to carcinogenic and non-carcinogenic effects. The noncarcinogenic impact is higher for children (more than 86\%) and 50\% for adults (D. Sun et al., 2018). Generally, heavy metals can impact human health caused by ingestion (eating and drinking) and inhalation (breathing). The metal ions high risks contaminants are arsenic, barium, lead, cadmium, chromium, mercury, silver, and selenium.

Arsenic is one of the metal ions. Arsenic can be released in larger quantities due to volcanic activity, rocks erosion, forest fire, and human activity. In the USA, arsenic is found in paints, metals, dyes, drugs, semi-conductor, and soaps. Arsenic harms human health. This metal can generate cancer of the skin, bladder, liver, and lungs. The lower level of exposure can cause nausea and vomiting, decreased white and red blood cell production, ingestion of high contaminated can result in death, longterm low-level exposure can cause a darkening of small corns' appearance warts palms, torso, and soles, and skin. EPA (Environmental Protection Agency) has reported regulatory limits of arsenic in drinking water $(0.01 \mathrm{ppm}$-parts per million-), OSHA (Occupational Safety and Health Administration) also said 10 micrograms per cubic meter of workplace air in $10 \mu . \mathrm{m}^{-3}$ for eight-hour shifts and forty-hour work per weeks (Adriano, 2001)

One of the very abundant metal is barium. This metal is naturally occurring and used for industrial purposes. One barium compound is barium-nickel alloys, barium-nickel alloys used in spark-plug electrodes, and vacuum tubes as a drying and oxygen-removing agent. The health effects on barium are cancer. Short-term barium exposure is vomiting, diarrhea, abdominal cramps, breathing difficulties, decreased blood pressure, numbness around the face, and muscle weakness. Large amounts of barium contaminated can cause high blood pressure, change in heart rhythm, paralysis until death possibility. International organizations that regulate the limits of barium are EPA and OSHA. The EPA has limited barium contaminants, is $2.0 \mathrm{ppm}$ in drinking water, and 0.5 milligrams of soluble barium compounds per cubic meter of the workplace for eight hours of work in a day and a 40-hour workweek. A recent study informs that barium is public awareness. Contamination of barium in a human occurs via inhalation, and ingestion a compound has barium content $(\mathrm{BaCl} 2)$. This compound has been recognized as a human toxin since 1940, causes diarrhea, vomiting, cardiac, arrhythmia, kidney failure and liver, tremors (disorders of the nervous 
system), brain swelling, and paralysis (Kravchenko et al., 2014).

One of very toxic metal is cadmium, cadmium, and cadmium compounds are known as human carcinogens. The high contaminated cadmium is a smoker. Cadmium can find in several products such as batteries, pigments, plastics, and metal coatings. Diarrhea, vomiting and irritates the stomach are ingesting a very high level. Fragile bones, lung damage, are a disease caused by cadmium in lower long-term exposure levels. Regulatory limits of cadmium in drinking water also reported by EPA, Food and Drug Administration (FDA), and OSHA: 5 parts per billion (ppb) or $0.005 \mathrm{ppm}$ in drinking water for EPA and FDA and 5 micrograms per cubic meter of workplace air for eighthour workday or 40-hour works week. Chromium ( $\mathrm{Cr}$ ) is one of the metal toxicology. This metal is found in rocks, soil, plants and can be in a liquid, solid, or gas phase. Breathing levels can irritate the lining of the nose ulcers, nose, runny nose, and breathing problems. Contact of $\mathrm{Cr}$ and skin can cause skin ulcers. Allergic and long-term exposure can cause damage to the liver, as well as skin irritation. EPA, FDA, and OSHA also reported that the limit of $\mathrm{Cr}$ in drinking water is $0.1 \mathrm{ppm}, 1$ milligram per liter, and average between 0.0005 and 1.0 milligram per cubic meter in the workplace eight-hour workday, or 40hour work in a week. Lead, Mercury, Selenium, and silver also affected some negative impacts on human health (Martin \& Griswold, 2009).

\section{Bioremediation for Wastewater treatment}

Bioremediation has been utilizing in several industries. One of the sectors that used bioremediation is aquaculture. This method has been operating in aquaculture sludge. This material can harm the environment. Thus, aquaculture sludge needs to be treated. A recent paper informs that aquaculture sludge treatment using bioremediation. Contaminated parameters of sludge in aquaculture are nitrogenous compound, phosphorous, and hydrogen sulfide. Thus, these parameters need to remove from aquaculture. Some species of microorganisms used to remediate wastewater in aquaculture, such as Marichromatium gracile YL28, this microorganism can reduce $99.96 \%$ in aquaculture pond in seven days. Bacillus pumilus and Lactobacillus delbruecki can reduce the total nitrogen ammonia after two months in the cap culture system. Nitrobacter, yeast, and Bacillus subtilis can remove $99.74 \%$ of total nitrogen and $62.78 \%$ phosphorous in brackish aquaculture waste (Jasmin et al., 2020).

Sun et al. (2019) reported that bioremediation also utilizes polycyclic aromatic hydrocarbon using Pseudomonas aeruginosa S5 was successfully prepared with isolated from cooking wastewater. This study reported seven strains capable of biosurfactant producing, this material produced from wastewater isolated (S. Sun et al., 2019). Other research informs the bioremediation of emerging contaminants using microalga bioremediation. Microalgae have been used to bioremediate nutrients such as phosphorous, nitrogen, and carbon from various wastewater. Microalgae bioremediation is a low-cost treatment for wastewater remediation. Another advantage of bioremediation-basedmicroalgae utilization is the ability to recover resources. This material also can re-use through biorefinery and the bacterial or microalgae. Bioadsorption by microalgae occurs when compounds either adsorbed to components of the cell or extracellular polysaccharides. Several emerging contaminant was reported could reduce with microalgal species, the emerging contaminants such as $17 \alpha-$ Boldenone, $17 \quad \beta$-Boldenone, $17 \alpha-$ Estradiol, $17 \beta$-Estadiol, these emerging 
contaminant can reduce by microalgal species such as mixed consortia, scenedesmus dimorphus, Chlamydomonas reinhardtii, Desmodesmus subspicatus, Nannochloris sp., Selenastrum Bioadsorption, biouptake and capricornutum (Sutherland \& Ralph, 2019)

Bioremediation is one of the lowcost and straightforward remediation for petroleum hydrocarbon contamination. This contaminant is some of the most extensively used chemicals in industrial activity and fuel. A recent study informs about 1.7 until 8.8 million metric tons of oil discharges to the global water resources each year. This condition made wastewater on a global scale, bioremediation including natural bioremediation and enhanced bioremediation involve decomposing contaminant to non-toxic products using microbial processes. This treatment has been used since the 1940s, including insitu and ex-situ process. These processes can be applied to bioremediation. Several factors affected the bioremediation using microbial such as microbial population, oxygen, water, nutrients, temperature, and $\mathrm{pH}$. Bioremediation has some limited such as sites are generally contaminated with a mixture of contaminants, but the microorganism can degrade them all, high concentration of pollutants may be inhibitory to microorganism, limited of electron acceptors and nutrient (Saini et al., 2019)

Bioremediation also may be to combine with electrochemistry (He et al., 2020). This treatment is also called microbial electrochemistry. Microbial electrochemistry non-spontaneous system is a technology for wastewater treatment using microbial electrochemistry, and another one is spontaneous microbial electrochemistry. Both of them are one of the combinations of remediation using living organisms (bioremediation) with electrochemical remediation (Ram et al.,
2018). A recent study informs that bioremediation for wastewater treatment using enzymes. This method can solve the pharmaceuticals from wastewater. Pharmaceutical is one of the organic chemical contamination in waste. This waste material can solve using biological advanced treatment methods such as membrane bioreactor (MBR), bio infiltration, managed aquifer recharge systems, and enzymatic processes. These processes typically low to moderate, moderate, and to be determined for enzymatic functions. The enzymatic processes are no biomass generation and have high selectivity; technical feasibility not proven, and longevity (Drewes et al., 2018)

A review and meta-analysis reported by Sebastian in 2019 about the application of bioturbators for marine bioremediation: in this review, authors informed about methodology, metaanalysis, bioremediation for nutrient release and oxygen uptake, bioremediation for metal remediation, bioturbation for sediments, factors of modulating effect of bioturbators, and future research directions. Human activities impacted significant contaminations for aquatic systems and gave some negatives effects on biodiversity and ecosystems. Bioturbators is one of technology that can combine with bioremediation. This treatment, also called bioturbation-bioremediation, the synthesis of the current study on bioturbation, highlights the possibility of this approach for contaminant remediation, especially wastewater. Based on this article, the author reported the significant impact of the contaminant's bioturbation method, accumulating decreasing bioavailability for the tropic level. A combination of bioturbators in bioremediation also noted that this technology could reduce metal in sediments (Vadillo et al., 2019). Still, in this article, the authors do not give 
information about the value of the metal decrease in sediments.

One important in bioremediation utilization is to solve the oil spill in the sea. It is caused by bioremediation is one of high efficiency than another treatment - bacteria used in hydrocarbondegrading in the marine environment. Researchers' current opinion is research must be directed to establishing in-situ condition for the growth of the oildecreasing bacteria. These bacteria need to develop near the toxic aromatic hydrocarbons (Ron \& Rosenberg, 2014). Besides, this treatment needs to grow on an industrial scale. Recent papers published were limited to the laboratory scale. However, the industrial-scale has to focus on environmental indicators such as ocean currents, wind direction, wind speed, number of bacteria needed, and other factors not to disturb the marine ecosystem.

\section{Opportunities and Challenges of Bioremediation}

Heavy metals removal using microbial treatment is an advantage, including adaptability: Selfreproductivity, recycling of bioproducts, eco-friendliness. In Indonesia, several regulations were created to support environmental remediation using bioremediation. An international company in oil and gas has been developing bioremediation since 1994. Firstly, the remediation using microbial set in lab-scale and has been applicable till now. Nine bioremediation facilities create $42,000 \mathrm{~m}^{3}$ of waste capacity. This technology was used in full scale in 2002. This condition indicated that bioremediation is not only applicable to the lab scale. Numbers of microbial were reported could reduce pollutants from wastewater such as Bacillus strain $\mathrm{H} 9$, Aspergillusterreus for $\mathrm{Cd}$, Pseudomonas aeruginosa, and Aspergillusniger for $\mathrm{Cr}$, Pseudomonas aeruginosa PU21 (Rip64), and Aspergillusnige for $\mathrm{Pb}$. Thiobacillus ferrooxidans and Schizosaccharomyces pombe for $\mathrm{Cu}$ and $\mathrm{Ni}$ could reduce using Pseudomonas spp., and Candida spp (Banik et al., 2014), and much of the microbial has not been developed as a remediation agent for wastewater.

The opportunities for this method are exceptionally potential than other processes. One of the low-cost and straightforward ways to solve heavy metals contaminated is adsorption. Much of the papers were published about this method to solve heavy metals contamination. Still, when the adsorbent will adsorb the metals, at the same time, adsorbent changed into hazardous waste (due to metals contamination). This phenomenon needs to be treated by another technology. Thus, we need to pay more to reduce the metals contaminated from the adsorbent. However, this method too different. Microbial will be dead when the metals cannot find. The metals are food for the microbial consortia-however, the bioremediation treatment using microbial needs much cost to produce than the adsorption method.

For contaminant degradation biologically to work well, the pollutants must be in a bioavailable condition. The efficiency of contact between microorganisms and contaminants must be maximized. Physically, microorganisms assimilate contaminants in the liquid phase. It is difficult to degrade contaminants from a phase categorized as denser and hydrophobic (NAPLs) to be absorbed to diffuse out of the nanopores. In such cases, the rate of biodegradation can be controlled by the degree of diffusion, desorption, or solubility. More water-soluble (polar) contaminants are available. It is also necessary to increase the contact between microorganisms-contaminants, especially in hydrophobic pollutants, namely the addition of surface-active agents (surfactants). Bioavailability includes the 
influence of all physical and chemical parameters that ultimately determine the potential utilization of microbes in utilizing these contaminant compounds.

Co-remediation technology such as permeable reactive barrier, electrokinetic system, microbial electrochemical technology, and others may enhance heavy metals' bioremediation process. Many coupling technologies show great potential to reduce heavy metals and other pollutants that contain in the wastewater. Research

Table 1. Cost of Bioremediations

\begin{tabular}{|c|c|c|c|c|}
\hline \multirow{2}{*}{$\begin{array}{c}\text { Type of } \\
\text { bioremediation }\end{array}$} & \multicolumn{2}{|c|}{ Cost USD/m } & \multicolumn{2}{c|}{ Benefits } \\
\cline { 2 - 5 } & Min & Max & TPH\% & Time (weeks) \\
\hline Land-Venting & 30 & 70 & 91.15 & 4 \\
\hline Bio-cell & 45.2 & 53.4 & 57.14 & 12 \\
\hline Composite & 62 & 250 & 53 & 3 \\
\hline Bioventing & 109 & 928 & 82.21 & 5 \\
\hline Bio-slurry & 130 & 210 & 34 & 3 \\
\hline Phytoremediation & 21.53 & 75.35 & 36 & 1.5 \\
\hline
\end{tabular}

*TPH : Total petroleum hydrocarbons

Source: (Sasongko et al., 2017)

\section{Conclusion and Future Research Direction}

The review highlights the essential information for the utilization of bioremediation for environmental remediation. Bioremediation was classified into in-situ and ex-situ bioremediation. In-situ bioremediation techniques can be classified into intrinsic bioremediation and engineered in-situ bioremediation, and ex-situ bioremediation can be classified into solid-phase system and slurry phase system. Bioremediation techniques are also organized to bioaugmentation, biofilters, bioreactors, bio-stimulation, bio-venting, composting, landfarming, or land treatment or prepared bed bioreactors, bio-piling. Heavy metals are toxic material in the environment. These materials also dangerous and have some negative impacts on the environmental and human health. Heavy metals in the in this area is still growing, especially to find a suitable coupling technology that could significantly reduce pollutants and low operational and investment costs.

\section{Economic Analysis}

Bioremediation techniques were used in Indonesia. Several bioremediations techniques such as land vesting, bio-cell, composite, bioventing, bio-slurry and phytoremediation can be seen in table below. 
an industrial scale. Finally, based on the importance of the bioremediation process for waste materials treatment.

\section{REFERENCE}

Adams, G. O., Fufeyin, P. T., Okoro, S. E., \& Ehinomen, I. (2015). Bioremediation, Biostimulation and Bioaugmention: A Review. International Journal of Environmental Bioremediation \& Biodegradation, 3(1), 28-39. https://doi.org/10.12691/ijebb-3-1-5

Adriano, D. C. (2001). Arsenic. In Trace Elements in Terrestrial Environments (pp. 219-261).

Banik, S., Das, K., Islam, M., \& Salimullah, M. (2014). Recent Advancements and Challenges in Microbial Bioremediation of Heavy Metals Contamination. JSM Biotechnology \& Biomedical Engineering, 2(1), 1035.

Bwapwa, J. K., Jaiyeola, A. T., \& Chetty, R. (2017). Bioremediation of acid mine drainage using algae strains : A review. South African Journal of Chemical Engineering, 24(April), 62-70.

https://doi.org/10.1016/j.sajce.2017. 06.005

Channel, B., Giarratano, E., Amin, O. A., Conicet, C., Houssay, A. B., Ushuaia, V., \& Fuego, T. (2010). Ecotoxicology and Environmental Safety Heavy metals monitoring in the southernmost mussel farm of the world. Ecotoxicology and Environmental Safety, 73(6), 13781384.

https://doi.org/10.1016/j.ecoenv.201 0.06 .023

Chen, Y., de Oliveira, L. M., da Silva, E. B., Dong, X., Ma, L. Q., \& Li, H. (2017). Mechanisms of metal sorption by biochars: Biochar characteristics and modifications. Chemosphere, 178, 466-478. https://doi.org/10.1016/j.chemospher e.2017.03.072

Drewes, E., Grassmann, J., Stadlmair, L. F., \& Letzel, T. (2018). Chemosphere Enzymes in removal of pharmaceuticals from wastewater: A critical review of challenges , applications and screening methods for their selection. Chemosphere, 205, 649661.

https://doi.org/10.1016/j.chemospher e.2018.04.142

Goltapeh, E. M., Danesh, Y. R., \& Varma, A. (2013). An Introduction to Bioremediation. In Soil Biology (Vol. 32, Issue January 2013, pp. 203-226).

https://doi.org/10.1007/978-3-64233811-3

Hatzinger, P. B., Whittier, M. C., Arkins, M. D., Bryan, C. W., \& Guarini, W. J. (2002). In-situ and ex-situ bioremediation options for treating perchlorate in groundwater. Remediation, 12(2), 69-86. https://doi.org/10.1002/rem.10026

He, Y., Wang, X., Aulenta, F., \& Estevenú, A. (2020). Environmental Science and Ecotechnology Microbial electrochemistry for bioremediation. $\quad$ (January). https://doi.org/10.1016/j.ese.2020.10 0013

Hunkeler, D., Höhener, P., \& Zeyer, J. (2002). Engineered and subsequent intrinsic in situ bioremediation of a diesel fuel contaminated aquifer. Journal of Contaminant Hydrology, 59(3-4), 231-245. https://doi.org/10.1016/S01697722(02)00059-1

Jasmin, M. Y., Syukri, F., Kamarudin, M. S., \& Karim, M. (2020). Potential of bioremediation in treating aquaculture sludge: Review article. Aquaculture, 519, 734905. https://doi.org/10.1016/j.aquaculture .2019 .734905 
Jones, S. C., \& Wilson, K. C. (1993). Bioremediation of soil contaminated with polynuclear aromatic hydrocarbons (PAHs): A review. Environmental Pollution, 81(3), 229-249.

Karigar, C. S., \& Rao, S. S. (2011). Role of microbial enzymes in the bioremediation of pollutants: A review. Enzyme Research, 2011(1). https://doi.org/10.4061/2011/805187

Kravchenko, J., Darrah, T. H., Miller, R. K., \& Lyerly, H. K. (2014). A review of the health impacts of barium from natural and anthropogenic exposure. Environmental Geochemistry and Health, 34(4), 797-814. https://doi.org/10.1007/s10653-0149622-7

Loehr, B. R. C., Smith, J. R., \& Corsi, R. L. (2001), and Svoc E Missions From S Lurry and S Olid P Hase. Practice Periodical of Hazardous, Toxic and Radioactive Waste Management, 5(4), 211-224.

Martin, S., \& Griswold, W. (2009). Human Health Effects of Heavy Metals. Nd Technology Briefs for Citizens Page 1 Environmental Science and Technology Briefs for Citizens, 15, 1-6.

Megharaj, M., Ramakrishnan, B., Venkateswarlu, K., Sethunathan, N., \& Naidu, R. (2011). Bioremediation approaches for organic pollutants: A critical perspective. Environment International, 37(8), 1362-1375. https://doi.org/10.1016/j.envint.2011 .06 .003

Men, C., Liu, R., Xu, L., Wang, Q., Guo, L., Miao, Y., \& Shen, Z. (2019). Source-specific ecological risk analysis and critical source identification of heavy metals in road dust in Beijing, China. Journal of Hazardous Materials, 377, 1-42. https://doi.org/10.1016/j.jhazmat.20 19.121763
Mendoza, R. N., Medina, T. I. S., Vera, A., Rodriguez, M. A., \& Guibal, E. (2007). Study of The Sorption of Cr(Iii) With XAD-2 Resin Impregnated with DI- $(2,4,4$ Trimethylpentyl)Phosphinicacid (Cyanex 272). Solvent Extraction and Ion Exchange, 18(2), 37-41. https://doi.org/10.1080/0736629000 8934684

Menendez-Vega, D., Gallego, J. L. R., Pelaez, A. I., Fernandez de Cordoba, G., Moreno, J., Muñoz, D., \& Sanchez, J. (2007). Engineered in situ bioremediation of soil and groundwater polluted with weathered hydrocarbons. European Journal of Soil Biology, 43(5-6), 310-321.

https://doi.org/10.1016/j.ejsobi.2007 .03 .005

Naswir, M., Arita, S., Hartati, W., Septiarini, L., Desfaournatalia, D., \& Wibowo, Y. G. (2019). Activated Bentonite: Low Cost Adsorbent to Reduce Phosphor in Waste Palm Oil. International Journal of Chemistry, 11(2), 67. https://doi.org/10.5539/ijc.v11n2p67

Oya, N., Keskin, S., Celebioglu, A., Sarioglu, O. F., Uyar, T., \& Tekinay, T. (2017). Encapsulation of Living Bacteria in Electrospun Cyclodextrin Ultrathin Fibers for Bioremediation of Heavy Metals and Reactive Dye from Wastewater. Colloids and Surfaces B: Biointerfaces, 161, 169-176. https://doi.org/10.1016/j.colsurfb.20 17.10.047

Peruchi, L. M., Fostier, A. H., \& Rath, S. (2015). Sorption of norfloxacin in soils: Analytical method, kinetics and Freundlich isotherms. Chemosphere, 119, 310-317. https://doi.org/10.1016/j.chemospher e.2014.06.008

Ram, C. A., Prado, A., Arias, C. A., Esteve-n, A., \& Brix, H. (2018). 
Microbial

Electrochemical

Technologies for Wastewater

Treatment : Principles and Evolution from Constructed Wetlands. Water, 10(1128), 1-29. https://doi.org/10.3390/w10091128

Rayu, S., Karpouzas, D. G., \& Singh, B. K. (2012). Emerging technologies in bioremediation: constraints and opportunities. Biodegradation, 23, 917-926.

https://doi.org/10.1007/s10532-0129576-3

Ron, E. Z., \& Rosenberg, E. (2014). Enhanced bioremediation of oil spills in the sea. Current Opinion in Biotechnology, 27, 191-194. https://doi.org/10.1016/j.copbio.201 4.02.004

Saini, A., Bekele, D. N., Chadalavada, S., Fang, C., \& Naidu, R. (2019). A review of electrokinetically enhanced bioremediation technologies for PHs. Journal of Environmental Sciences, 88, 31-45. https://doi.org/10.1016/j.jes.2019.08 .010

Sasongko, N. A., Agustiani, R., \& Khotimal, K. (2017). Analisis Biaya Manfaat Berbagai Jenis Teknik Remediasi Air Terproduksi dari Kegiatan Industri Minyak dan Gas Bumi. Jurnal Energi Dan Lingkungan, 13(2), 79-86.

Science, L., \& Sharma, S. (2012). Bioremediation: Features, Strategies and applications. Asian Journal of Pharmacy and Life Science, 2(2), 202-213.

Sharma, S., Nagpal, A. K., \& Kaur, I. (2019). Appraisal of heavy metal contents in groundwater and associated health hazards posed to human population of Ropar wetland, Punjab, India and its environs. Chemosphere, 227, 179-190. https://doi.org/10.1016/j.chemospher e.2019.04.009
Sun, D., Zhang, D.-X., Wu, W., Wu, P., Zhou, Y.-K., \& Yang, F. (2018). Assessment of heavy metal pollution and human health risks in urban soils around an electronics manufacturing facility. Science of The Total Environment, 630, 53-61. https://doi.org/10.1016/j.scitotenv.2 018.02.183

Sun, S., Wang, Y., Zang, T., Wei, J., Wu, H., \& Wei, C. (2019). Bioresource Technology A biosurfactantproducing Pseudomonas aeruginosa S5 isolated from coking wastewater and its application for bioremediation of polycyclic aromatic hydrocarbons. Bioresource Technology, 281(February), 421428.

https://doi.org/10.1016/j.biortech.20 19.02.087

Susanti, T., Utami, W., \& Amimi, D. (2018). The negative impact of illegal gold mining on the environmental sector in Batang Asai , Jambi. Journal of Environmen and Sustainability, 2(3), 128-143. https://doi.org/10.22515/sustinere.je s.v2i3.43

Sutherland, D. L., \& Ralph, P. J. (2019). Microalgal bioremediation of emerging contaminants Opportunities and challenges. Water Research, 164, 114921. https://doi.org/10.1016/j.watres.201 9.114921

Vadillo, S., Johnston, E., Gribben, P. E., \& Dafforn, K. (2019). The application of bioturbators for aquatic bioremediation: Review. Environmental Pollution, 250, 426436.

https://doi.org/10.1016/j.envpol.201 9.04.023

Venkata Mohan, S., Purushotham Reddy, B., \& Sarma, P. N. (2009). Ex situ slurry phase bioremediation of chrysene contaminated soil with the function of metabolic function: 
Process evaluation by data enveloping analysis (DEA) and Taguchi design of experimental methodology (DOE). Bioresource Technology, 100(1), 164-172. https://doi.org/10.1016/j.biortech.20 08.06.020

Verma, S., \& Kuila, A. (2019). Environmental Technology \& Innovation Bioremediation of heavy metals by microbial process. Environmental Technology \& Innovation, $\quad 14, \quad 100369$. https://doi.org/10.1016/j.eti.2019.10 0369

Villegas-plazas, M., Sanabria, J., \& Junca, H. (2019). A composite taxonomical and functional framework of microbiomes under acid mine drainage bioremediation systems. Journal of Environmental Management, 251(September), 109581.

https://doi.org/10.1016/j.jenvman.20 19.109581

Wang, P., Sun, Z., Hu, Y., \& Cheng, H. (2019). Science of the Total Environment Leaching of heavy metals from abandoned mine tailings brought by precipitation and the associated environmental impact. Science of the Total Environment, 695, 133893. https://doi.org/10.1016/j.scitotenv.2 019.133893

Werner, T. T., Bebbington, A., \& Gregory, G. (2019). The Extractive Industries and Society Assessing impacts of mining: Recent contributions from GIS and remote sensing. The Extractive Industries and Society, June, 0-1. https://doi.org/10.1016/j.exis.2019.0 6.011

Wibowo, Y. G., \& Naswir, M. (2019). A Review of Biochar as a Low - cost Adsorbent for Acid Mine Drainage Treatment. Prosiding Seminar
Nasional Hari Air Dunia 2019, 110.

Wibowo, Y. G., Ramadan, B. S., \& Andriansyah, M. (2019). Simple Technology to Convert Coconut Shell Waste into Biochar; A Green Leap Towards Achieving Environmental Sustainability. Jurnal Presipitasi : Media Komunikasi Dan Pengembangan Teknik Lingkungan, 16(2), 58. https://doi.org/10.14710/presipitasi.v 16i2.58-64

Wibowo, Y. G., \& Syarifuddin, H. (2018). Rancangan Dimensi Pada Tambang Terbuka Sebagai Upaya Pencegahan Kerusakan Lingkungan Yang Diakibat Oleh Air Asam Tambang. Semnas SINTA FT UNILA, 1, 49-53.

Wilson, A. (2006). Your Green Home; A Guide to Planning a Healthy, Environmentally Friendly New Home. New Society Publisher.

Xia, S., Song, Z., Jeyakumar, P., Shaheen, S. M., Rinklebe, J., Ok, Y. S., Bolan, N., \& Wang, H. (2019). Technology A critical review on bioremediation technologies for $\mathrm{Cr}$ ( VI ) -contaminated soils and wastewater. Critical Reviews in Environmental Science and Technology, $\quad 0(0), \quad 1-52$. https://doi.org/10.1080/10643389.20 18.1564526

Yang, H., Tao, W., Liu, Y., Qiu, M., Liu, J., Jiang, K., \& Yi, K. (2019). The contribution of the Beijing , Tianjinand Hebeiregion' $\mathrm{s}$ iron and steel industry to local air pollution in winter *. Environmental Pollution, 245 ,

1095-1106. https://doi.org/10.1016/j.envpol.201 8.11.088

Zhang, B., Guo, Y., Huo, J., Xie, H., Xu, C., \& Liang, S. (2019). Combining chemical oxidation and bioremediation for petroleum polluted soil remediation by $\mathrm{BC}$ - 
Bioremediations Technologies on ...,...Rosanti, D., Wibowo, Y. G., Safri, M., Maryani, A. T. and Ramadan, B. S.,...Sainmatika,...Volume 17,...No.2,...December 2020,...142-156

nZVI activated persulfate. Chemical Engineering Journal, 709, 123055. https://doi.org/10.1016/j.cej.2019.12 3055

Zhou, Q., Yang, N., Li, Y., Ren, B., Ding, X., Bian, H., \& Yao, X. (2020). Total concentrations and sources of heavy metal pollution in global river and lake water bodies from 1972 to 2017. Global Ecology and Conservation, e00925. https://doi.org/10.1016/j.gecco.2020. e00925 